\title{
Modern transformation of the production structure and its impact on the content of labor and the requirements for the skills and abilities of workers
}

\author{
Olga Rasskazova ${ }^{1}$, Olga Kalinina ${ }^{1, *}$ and Elizaveta Zotova ${ }^{1}$ \\ ${ }^{1}$ Peter the Great St.Petersburg Polytechnic University, Polytechnicheskaya, 29, 195251, St. Petersburg, \\ Russia
}

\begin{abstract}
The paper describes changes in the content and nature of work, which has occured in the sphere of labor and employment. Taking into account these changes, we determine the universal skills and abilities of workers which are important to master and develop in order to be competitive today. Universal competencies will allow workers to become more efficient in their jobs, and will help workers to be in demand while shifting between industries in the era of constant change and global competition.
\end{abstract}

\section{Introduction}

In modern society, the requirements for the skills and abilities of workers are constantly growing and transforming in the conditions of continuous changes and global competition. We observe an increasing automation, which allows organizations to be more productive and efficient and therefore more competitive. However, the increasing process of automation the use of robots, computer programs and artificial intelligence systems causes fear that the majority of workers may remain unemployed in the near future. Oxford researchers from the "Martin School's Programme on the Impacts of Future Technology" forecast that in developed countries in the next twenty years up to $45 \%$ of existing jobs will be replaced by robots and programs [1]. To avoid just being pessimistic about this matter, we should consider the transformations that have occurred (or will occur in the near future) in the content and nature of labor activity, and what skills and abilities should be mastered and improved for modern workers to be competitive in the conditions of constant changes of business.

\section{Results section}

Currently, scientists specify four global transformations of the industrial system, called industrial revolutions. They emerged in different countries in different periods, but in general, we can name the time periods when these changes took place in the society.

\footnotetext{
* Corresponding author: olgakalinina@,bk.ru
} 
- The end of the 18th century - the first industrial revolution: the introduction of machine production with the help of a steam engine (Industry 1:0). The basic innovation was the mechanical loom invented in 1784.

- The beginning of the 20th century - the second industrial revolution: the introduction of mass production through the use of electricity (Industry 2:0). The basic innovation was the conveyer invented in 1870 .

- The early seventies of the 20th century - the third industrial revolution: further automation of production with the help of electronics and on the basis of IT-technology (Industry 3:0). The basic innovation was the programmable logic controller invented in 1969. Despite the fact that the concept of the third industrial revolution has not been fully established, there is some concept even of the next industrial revolution.

- Our days - the fourth industrial revolution: production development based on the use of cyber-physical systems and machine-machine interaction; the emergence of a completely digital industry based on the interpenetration of information technology and industry (Industry 4:0). Fully-automated plants ("smart factories") are created in which lines and products interact with each other and with consumers within the concept of the "Internet of Things", which allows producing individualized products.

All these global transformations of the production structure have made changes in the labor content and working conditions, as well as work processes [1, 3, 7]. We will highlight the important characteristics (aspects) of labor activity, which have changed significantly in recent years. Table 1 shows two time periods: the first period ("It was") covers the second and partly the beginning of the third industrial revolution, the second period ("It is / It will be") describes the height of the era of the third industrial revolution and the fourth industrial revolution.

Table 1. Evolution of the characteristics of labor activity.

\begin{tabular}{|c|c|c|c|}
\hline № & $\begin{array}{l}\text { Characteristics of } \\
\text { labor activity }\end{array}$ & Period "It was" & Period "It is / It will be" \\
\hline 1 & $\begin{array}{l}\text { Changes to the } \\
\text { essence of work } \\
\text { and problems } \\
\text { encountered by } \\
\text { the worker }\end{array}$ & $\begin{array}{l}\text { Fewer single-function jobs } \mathrm{s} \\
\text { ("job - function") when an } \\
\text { expert was a worker who } \\
\text { performed a particular } \\
\text { function, and a team solved } \\
\text { primarily one business } \\
\text { problem. Labor activity } \\
\text { embraced only one } \\
\text { professional } \\
\text { (profession), } \\
\text { which was a source of income } \\
\text { and self-identification. }\end{array}$ & $\begin{array}{l}\text { The emergence of the job as a diverse } \\
\text { set of projects ("work in projects"), } \\
\text { when it is necessary to solve various } \\
\text { complex business tasks, which can be } \\
\text { constantly changing. The same (or } \\
\text { different) workers are involved in } \\
\text { different projects. Frequent change of } \\
\text { the line of activity, absence of a single } \\
\text { profession. }\end{array}$ \\
\hline 2 & $\begin{array}{l}\text { The scale of the } \\
\text { company's } \\
\text { activity }\end{array}$ & $\begin{array}{l}\text { The company's activities } \\
\text { were concentrated mainly in } \\
\text { one sector of the economy, } \\
\text { and professionals were } \\
\text { required to understand its } \\
\text { specificity (technology, } \\
\text { processes, professional } \\
\text { language). }\end{array}$ & $\begin{array}{l}\text { The interaction of business partners } \\
\text { from different (adjacent) sectors of } \\
\text { the economy. They should have the } \\
\text { skills of cross-sectoral } \\
\text { communication and be able to } \\
\text { develop flexible technological } \\
\text { solutions to the tasks. }\end{array}$ \\
\hline 3 & $\begin{array}{l}\text { The attitude of } \\
\text { workers to change }\end{array}$ & $\begin{array}{l}\text { Companies operated in a } \\
\text { situation of relative stability } \\
\text { and certainty. Workers had a } \\
\text { negative attitude to emerging } \\
\text { organizational changes }\end{array}$ & $\begin{array}{l}\text { The company operates in a situation } \\
\text { of constant changes and uncertainty } \\
\text { (changing business players, rules of } \\
\text { business, customers, produced gooods } \\
\text { and services). The readiness of }\end{array}$ \\
\hline
\end{tabular}




\begin{tabular}{|c|c|c|c|}
\hline & & & $\begin{array}{l}\text { workers to change becomes the most } \\
\text { important corporate competence. }\end{array}$ \\
\hline 4 & $\begin{array}{l}\text { The major style of } \\
\text { management }\end{array}$ & $\begin{array}{l}\text { Companies preferred to use a } \\
\text { hierarchical style of } \\
\text { management, to establish } \\
\text { standard processes of } \\
\text { management and production. }\end{array}$ & $\begin{array}{l}\text { Companies are not afraid to } \\
\text { experiment and take risks. Big } \\
\text { companies will avoid rigid job } \\
\text { hierarchies and will try to introduce } \\
\text { the horizontal management style, } \\
\text { such as "holacracy". The work } \\
\text { process aims at maximum efficiency } \\
\text { by giving each team member the } \\
\text { opportunity to be a leader. It is } \\
\text { expected that the business will be } \\
\text { supported by a small group of key } \\
\text { workers, and freelancers will be } \\
\text { employed for other roles on a } \\
\text { contractual basis. }\end{array}$ \\
\hline 5 & Working hours & $\begin{array}{l}\text { Full-time jobs (full working } \\
\text { day, full-time week). }\end{array}$ & $\begin{array}{l}\text { Part-time jobs (part-time working } \\
\text { day, part-time week). }\end{array}$ \\
\hline 6 & Labor contract & $\begin{array}{l}\text { Standard labor contract, } \\
\text { confirming } \quad \text { standardized } \\
\text { conditions of employment for } \\
\text { industries and professions. }\end{array}$ & $\begin{array}{l}\text { Destandardization of the labor } \\
\text { contract, employment without } \\
\text { registration, self-employment. }\end{array}$ \\
\hline 7 & $\begin{array}{l}\text { The location of a } \\
\text { workplace (office) }\end{array}$ & $\begin{array}{l}\text { Labor activity in a "real } \\
\text { office" - workers were jointly } \\
\text { involved in the activity, } \\
\text { solved business-problems } \\
\text { and worked in a certain } \\
\text { workplace (office), provided } \\
\text { by the company. }\end{array}$ & $\begin{array}{l}\text { Labor activity in a "virtual office" - } \\
\text { workers perform a joint activity, but } \\
\text { are not in the same office. The } \\
\text { popularity of remote work grows } \\
\text { when an employee works from home, } \\
\text { communicating with the colleagues } \\
\text { via the Internet. } \\
\text { If offices are provided by the } \\
\text { employer, they are designed to ensure } \\
\text { a creative, cozy home-like } \\
\text { environment, the distinction between } \\
\text { the office and home is eliminated } \\
\text { (special recreational places, cozy } \\
\text { furniture, etc.). }\end{array}$ \\
\hline 8 & $\begin{array}{l}\text { The features of a } \\
\text { work team }\end{array}$ & $\begin{array}{l}\text { "United team": workers } \\
\text { performed a joint activity and } \\
\text { worked in the same company. }\end{array}$ & $\begin{array}{l}\text { "Distributed teams": workers perform } \\
\text { a joint activity, but are in different } \\
\text { companies, cities, countries. }\end{array}$ \\
\hline 9 & $\begin{array}{l}\text { Language skills } \\
\text { for business } \\
\text { communication }\end{array}$ & $\begin{array}{l}\text { Language of the country } \\
\text { where business problems are } \\
\text { solved was mainly used for } \\
\text { business communication. } \\
\text { Knowledge of a foreign } \\
\text { language by an worker was a } \\
\text { significant competitive } \\
\text { advantage. }\end{array}$ & $\begin{array}{l}\text { Communication can take place in a } \\
\text { foreign language(s). Moreover, } \\
\text { workers/partners are not expected } \\
\text { just to be fluent, but also have a } \\
\text { professional level, preferably with the } \\
\text { knowledge of the specifics of related } \\
\text { business sectors. }\end{array}$ \\
\hline 10 & $\begin{array}{lr}\text { Level } & \text { of } \\
\text { understanding } & \text { of } \\
\text { the cultural } \\
\text { context } \\
\text { communication }\end{array}$ & $\begin{array}{l}\text { Business was traditionally } \\
\text { carried out at the local level, } \\
\text { hence there was a common } \\
\text { understanding of the culture } \\
\text { of the country. }\end{array}$ & $\begin{array}{l}\text { The understanding of the national and } \\
\text { cultural context of the partner } \\
\text { countries is becoming relevant. }\end{array}$ \\
\hline 11 & $\begin{array}{l}\text { Work biography } \\
\text { of an employee } \\
\text { (career) }\end{array}$ & $\begin{array}{l}\text { Standardized, continuous, } \\
\text { progressive, upward, finite } \\
\text { working biography (career), } \\
\text { with a sequential change of } \\
\text { jobs and positions until }\end{array}$ & $\begin{array}{l}\text { Individualized, discrete } \\
\text { (intermittent), non-directional, with } \\
\text { no clear final boundaries. }\end{array}$ \\
\hline
\end{tabular}




\begin{tabular}{|l|l|l|l|}
\hline & & retirement. & \\
\hline 12 & $\begin{array}{l}\text { Wages and social } \\
\text { protection }\end{array}$ & $\begin{array}{l}\text { Provided life of a worker and } \\
\text { their family. } \\
\text { Full "social package", "good" } \\
\text { pension. }\end{array}$ & $\begin{array}{l}\text { Every single job is not able to ensure } \\
\text { the life of the employee, several } \\
\text { sources of income. } \\
\text { Poor social security, small pension. }\end{array}$ \\
\hline
\end{tabular}

In industrial society, the classic (full employment) system was based on the standardization of the main aspects of labor. It gave workers the sense of stability in life, there was a clear line between employment and unemployment. In post-industrial society, employment becomes combined or part-time, and non-traditional forms of employment based on flexibility and variability are widespread. They combine the elements of employment and unemployment and have many risks [9-13].

Today, automation is a requirement of global competition that gives companies a significant competitive advantage. Robots, computer programs, artificial intelligence systems are more productive or efficient than workers performing the same work. This situation in the labor market dictates that the process of increasing automation is perceived as a competitor to traditional workers. However, such substitution does not mean that people will be completely unemployed. The altered content of the work, requiring a creative approach in solving complex business problems, as well as growing joint activities in the project groups, changes this one-sided view of the situation. It is necessary to begin to perceive robots, computer programs, artificial intelligence systems as assistants and be able to customize them for the tasks chosen by a human.

Experts note [1] that the next five to seven years will lead to significant changes in quality standards and labor efficiency due to the proliferation of robotics, use of new materials and mobile devices. As a result, there will be substantial changes in all large-scale professional areas, so even today the boundaries of jobs and competencies are expanding.

On the basis of the abovementioned labor sphere trends, we can reasonably define generic skills and abilities (competencies) of Industry 4:0 workers [8]. By using and improving them, workers will become more successful and flexible, and adapt to the requirements of the employer and the dynamically changing labor market. Such universal skills and abilities, which are important for specialists from different sectors, include:

- customer-oriented approach;

- $\quad$ project and process management;

- activity in the conditions of uncertainty;

- multilingualism;

- multiculturalism;

- $\quad$ systems thinking;

- interdisciplinarity;

- computer literacy;

- $\quad$ ability to work with groups and individuals;

- creativity;

- ecological thinking;

- lean production.

Let us consider the abovementioned universal skills and abilities in more detail.

\subsection{Customer-oriented approach}

Customer-oriented approach is the ability of the company to create an additional flow of customers and additional profits by means of deep understanding and meeting the needs of customers. Its main criteria are the following qualities and skills of an employee: selfconfidence and confidence in the product, the ability to persuade, positive reinforcement, 
complete information awareness about the product or service, openness and willingness to meet the client's needs, and the ability to adapt quickly in any situation. A high level of competition that exists in any area, requires that the worker should have these skills and abilities.

\subsection{Project and process management}

Today and in the near future there will be more and more jobs where work is organized as a set of different projects which include solving complex business problems that can constantly change. For the majority of workers who perform activities in projects the following skills will become important: to work in project teams, organize projects independently, and act quickly and flexibly in unstable conditions.

\subsection{Activity in the conditions of uncertainty}

In order to act quickly and flexibly in the conditions of high uncertainty workers need to have certain skills and abilities. Namely, they should be able to make quick decisions, to react quickly to changes in working conditions, to allocate and redistribute limited resources, to manage their time in an ever-changing flow of work tasks.

\subsection{Multilingualism}

Due to globalization, workers, as a part of their work, have begun to interact with partners and colleagues from around the world. In these circumstances, when some of the workers and partners are located in other countries, the standards and methods of interaction in business have begun to change. Such forms of interaction as "virtual office" and "distributed teams" have emerged. Accordingly, the requirements for fluency in a foreign language have become more stringent. There is a need for the ability to communicate in international professional language(s), and to know the specifics of industry processes, requirements, standards. There will also be a need for a significant number of workers to speak the language of interdisciplinary communication, helping people from different professional fields (for example, their suppliers and consumers).

\subsection{Multiculturalism}

This skill implies the ability to communicate effectively with business partners and clients regardless of cultural differences. In today's business world, the knowledge of a foreign languages is becoming insufficient. The peculiarities of cultures of different peoples, their customs and traditions, ethical and moral norms have to be studied.

The level of system thinking illustrates the speed and quality of decision-making, demonstrates the ability to quickly understand how complex systems are arranged (organizations, processes, mechanisms, etc.). Modern labor activity is characterized by increasing complexity of work, constant readiness of workers for changes, finding flexible technological solutions. This situation actualizes the need in the labor market for specialists and managers who are able to perform complex business tasks, and manage projects, teams and entire organizations effectively. The main qualities of system thinking are the ability to effectively analyze large amounts of information; the ability to identify patterns and to form a holistic picture of what is happening; the ability to assess the risks and opportunities associated with a decision-making process [6]. 


\subsection{Systems thinking}

The level of systems thinking illustrates the speed and quality of decision-making, and demonstrates the ability to quickly understand how complex systems are arranged (organizations, processes, mechanisms, etc.). Modern labor activity is characterized by an increasing complexity of work, constant readiness of workers to change and find flexible technological solutions. This situation actualizes the need for specialists and managers who are able to perform complex business tasks, effectively manage projects, teams and entire companies. The main characteristics of systems thinking are the ability to effectively analyze large amounts of information; the ability to identify patterns and to form a holistic picture of what is happening; the ability to assess the risks and opportunities associated with a decisionmaking process [6].

\subsection{Interdisciplinarity}

Many problems and business challenges in the company require interdisciplinary solutions and intersectoral communication. Even today there is a need for versatile workers who are able to find a solution to any given task. An ideal worker is expected to be an expert in one field, as well as to have knowledge in another, related fields, and to talk to experts from other fields in one language. Such worker will be able to quickly find a solution to a complex problem, quickly enter a new field of activity and communicate ideas to people from other industries or sectors.

\subsection{Computer literacy}

In today's world, all parties involved labor activity (both workers and employers) understand the importance of basic computer literacy skills. However, today and in the near future this level of competence is becoming insufficient. Expanding the boundaries of professions and competencies requires that employees should become more proficient in this sphere. Elementary programming skills are required as a minimum (in industrialized countries, programming is becoming part of the standard training of blue-collars, because most of them operate machines with computer numerical control). Thus, in the near future programming of IT-solutions, management of sophisticated automated complexes, and work with artificial intelligence will become the natural elements of workers' computer literacy.

\subsection{Ability to work with groups and individuals}

More jobs will be associated with joint activities in groups, where great attention will be paid to team building and ability to interact with other people. One of the most important and widespread skills will be the skill of working with individuals and groups. Due to high technologies' development it is necessary to create an atmosphere that ensure effective management and productive workflow in virtual environment. The worker needs to learn how to collaborate with a virtual team as efficiently as if it was run by a manager in the office.

\subsection{Creativity}

The ongoing trends connected to global competition, functioning in the conditions of uncertainty, and client-oriented approach, will affect the content and nature of labor. A considerable part of work will become creative, it will be workers who are able to do it, not 
robots or computer programs. Artistic creativity and the developed aesthetic taste should become a mass phenomenon in the labor process.

\subsection{Ecological thinking}

Ecological thinking is characterized by a new comprehension of the world and a new approach to labor activity, based on teaching people about ecological and humanistic worldview, relying on the principles of environmental ethics. Modern workers need to develop skills of environmentally responsible behavior, understand that natural resources are limited, and everyone is responsible for their rational use. Ecological thinking can be seen in narrow and broad senses. In a narrow sense it is the advanced requirements for environmental compatibility of products and services.

\subsection{Lean production}

In a broad sense, environmental compatibility is lean production, that is, the management of the production process, based on a constant desire to eliminate all kinds of losses. It implies the involvement of each worker in the process of business optimization and maximum focus on the consumer. On the part of the worker and the employer it includes a lean attitude to natural resources (reduction of energy consumption, water consumption, etc.), and reduction in the amounts of waste (recycling, use of biodegradable materials, etc.).

\section{Conclusion}

In the modern conditions, the speed of changes increases. They affect the social and economic processes and the structure of professional tasks, whose complexity is forever increasing. In the context of change in the sphere of labor and employment, a number of universal skills that are important for specialists from different sectors have been identified. These skills will allow employees to become more efficient in their professional sphere and will give them the opportunity to be in demand while shifting between industries in the era of global competition.

\section{References}

1. The atlas of emerging jobs (Agency for strategic initiatives, Moscow school of management SKOLKOVO, Moscow, 2014)

2. Customer-oriented approach, http://bidbi.ru/articles/show/24.html

3. Y.N. Popov, O.V. Shevchuk, The modern economy and sociology of labor (EkonInform, Moscow, 2003)

4. L. Sankova, Personnel Management magazine, $5 \quad$ (2007) http://www.cfin.ru/management/people/hr_virtual.shtml

5. I.L. Sizova, T.M. Khusyainov, Bulletin of St. Petersburg University. Sociology 10, 376396 (2017)

6. Systems thinking - what is it? Characteristics and main features, http://fb.ru/article/250426/sistemnoe-myishlenie---eto-chto-takoe-harakteristiki-iosnovnyie-priznaki

7. Y.Y. Shatilo., E.S. Kopkova, Theory. Practice. Innovations, 11 (2017) 
8. 6 trends that define the working conditions in the near future, http://clblog.ru/2017/12/19/6-tendencij-opredelyayushhix-usloviya-truda-vblizhajshem-budushhem/

9. Future

Work

Skills

2020 http://od.msue.msu.edu/uploads/files/OD_docs/Future_Work_Skills_2020.pdf.

10. I.V. Ilin, V.I. Koposov, A.I. Levina, Life Science Journal 11, 265-269 (2014)

11. I.V. Ilin, O.V. Kalinina, A.I. Levina, O.Yu. Iliashenko, MATEC Web of Conferences, IPICSE 2016, 05028 (2016)

12. L.N.Nikolova, D. G. Rodionov, M.A.Bahauovna, International Journal of Economics and Financial 6(2) 246-252 (2016)

13. A. Mottaeva MATEC Web of Conferences, 106, 08071 (2017) https://doi.org/10.1051/matecconf/201710608071 